\title{
Statistical model for classifying the feeding systems of Iberian pigs through Gas Chromatography (GC-FID) and Isotope Ratio Mass Spectrometry (GC-C-IRMS)
}

\author{
By C.L. Delgado-Chavero ${ }^{a}$, E. Zapata-Márquez ${ }^{a}$, J.M. García-Casco ${ }^{b}$ \\ and A. Paredes-Torronteras ${ }^{a, *}$ \\ ${ }^{a}$ ASICI. Ctra. Ex101, km 4,7, 06300 Zafra (Badajoz) \\ ${ }^{b}$ Centro de I+D en Cerdo Ibérico - INIA. Ctra. Ex101, km 4,7, 06300 Zafra (Badajoz) \\ * Corresponding author: asici@asici.com
}

\section{RESUMEN}

Modelo estadístico para la clasificación de la alimentación de cerdos ibéricos a partir de Cromatografía de gases (CG-FID) y Espectrometría de masas de relaciones isotópicas (GC-C-IRMS)

En el presente trabajo se han analizado un total de 734 muestras de tejido subcutáneo de cerdos ibéricos con distintos tipos de alimentación de engorde (Bellota, Recebo, Cebo y Campo) a lo largo de tres años consecutivos, 2009-2011. Se han extraído los lípidos de la grasa subcutánea de rabadilla, y después de su esterificación, se han analizado por Cromatografía de gases (GC-FID) y por Espectrometría de masas de relaciones isotópicas (GC-C-IRMS). Las medias de los ácidos grasos y de las relaciones isotópicas muestran que existen diferencias según el año y tipo de alimentación factores que deberían tenerse en cuenta a la hora de clasificar los animales. La aplicación de distintos modelos de predicción basados en análisis discriminante permite establecer un método para la clasificación de los animales según el tipo de alimentación, con un porcentaje de aciertos del $85 \%$ utilizando tres o cuatro categorías de clasificación (Bellota, Recebo, Campo y/o Cebo) y del $91 \%$ utilizando sólo dos categorías, Cebo y Bellota. Este modelo podría sentar las bases para una clasificación adecuada del cerdo ibérico en función de su alimentación.

PALABRAS CLAVE: Ácidos Grasos - Cerdo Ibérico Cromatografía de gases - Espectrometría de masas de relaciones isotópicas - GC-C-IRMS - Grasa subcutánea.

\section{SUMMARY}

Statistical model for classifying the feeding systems of Iberian pigs through Gas Chromatography (GC-FID) and Isotope Ratio Mass Spectrometry (GC-C-IRMS)

In the present work we have analyzed a total of 734 subcutaneous fat samples from Iberian pigs with different feeding systems for fattening ("Bellota", "Recebo", "Campo" and "Cebo") over three consecutive years, 2009-2011. Lipids were extracted from the subcutaneous fat on the rump, and after esterification, they were analyzed by Gas Chromatography (GC-FID) and Gas ChromatographyCombustion-Isotope Ratio Mass Spectrometry (GC-C-IRMS). Mean fatty acids and isotope ratios show that there are differences according to the year and feeding systems, two factors that should be taken into account when classifying the animals. The application of different prediction models based on Discriminant analysis has allowed us to establish a method for the classification of animals according to the feeding system type, with a correct percentage of $85 \%$ using three or four classification categories (Bellota, Recebo, Campo and/or Cebo) and $91 \%$ using only two categories, Cebo and Bellota. This model could provide the basis for appropriate classification of Iberian pigs according to their feeding regime.

KEY-WORDS: Fatty acids - Gas Chromatography - GCC-IRMS - Iberian pig - Isotope Ratio Mass Spectrometry Subcutaneous fat.

\section{INTRODUCTION}

The analysis of the fatty acid composition of the subcutaneous adipose tissue lipids of Iberian pigs by GC-FID, was, until 2005, an effective and objective tool for the classification of carcasses based on the feed received by the animals during the final fattening period (Ruiz and Preton, 2001). In fact, it has been the only officially recognized method (B.O.E., 2004). The use of vegetable fats rich in oleic acid in formulated feed, which achieved a fatty acid profile in the animals' fat similar to animals which have consumed only grass and acorns, questioned the effectiveness of the GC-FID to determine the source of fatty acids deposited in adipose tissue and Iberian pork products. The Official Quality standard eliminated this technique for the classification of carcasses (B.O.E., 2007a), but in practice, it is a method that is still used by the industrial sector, because the composition of the intramuscular fat from meat plays a decisive role in the dry-cured process of the quality parts and determines, for example, the number of days required for the salting and drying of hams (Cava and Andres, 2001). It also influences the consistency, color and fat oxidation, which are decisive factors in the quality of the meat, both fresh and dry-cured (Melgar et al., 1991; Ruiz et al., 2000; Ventanas et al., 2006; Ventanas et al., 1999; Gilles, 2009).

As an alternative technique, González-Martin and collaborators used the determination of the isotopic ${ }^{13} \mathrm{C} /{ }^{12} \mathrm{C}$ ratio of the total carbon in the subcutaneous fat of Iberian pigs for the differentiation of feeding regimes (Gonzalez-Martin et al., 1999; GonzalezMartin et al., 2001; Gonzalez-Martin et al., 1998) which is reflected in relation to their diet (DeNiro et 
al., 1978). However, the use of certain formulated feed in the fattening of pigs can mask the results, so it has resulted in the separation of fatty acid methyl esters (FAMEs) by Gas Chromatography and subsequent combustion and mass spectrometry analysis of the ${ }^{13} \mathrm{C} /{ }^{12} \mathrm{C}$ isotope ratios of the products obtained, which create a characteristic isotope profile of each sample (Recio-Hernández, 2010). This technique, called GC-C-IRMS, is currently used for the detection of adulteration in vegetable oils (Spangenberg et al. 1998; Kelly et al., 1997, Kelly and Rhodes, 2002) and wine (Regulation EEC, 1990). Although the method proposed for the Iberian pig indicates the determination of at least four isotopic ratios of the major FAMEs in the fat (oleic, palmitic, linoleic and stearic acids), which would be the minimum necessary to provide positive identification information in the case of an Iberian Acorn-fed pig (Bellota), some industries are currently using only the oleic ${ }^{13} \mathrm{C} /{ }^{12} \mathrm{C}$ isotope ratio for the differentiation of the Iberian pig feeding regime, applying an index which sets limit values for classifying the animals in the Bellota category.

In order to compare the efficacy of these techniques, jointly or separately, samples of subcutaneous adipose tissue from Iberian pigs were analyzed both by Isotope Ratio Mass Spectrometry (GC-C-IRMS) and by Gas Chromatography (GCFID). A statistical study comparing the results and five different models using Discriminant analysis for the classification of samples has been made, calculating the correct percentage on several assumptions based on the number of feeding categories considered.

\section{MATERIAL AND METHODS}

\subsection{Samples}

Subcutaneous fat samples were taken on the day of slaughter from a total of 734 animals, belonging to 38 batches of Iberian pigs, reared and fattened in different farms in Extremadura, Andalusia and Salamanca. The feeding regime of these animals during the final fattening phase was known. Their classification, based on the Official method (B.O.E., 2007a), is shown in Table 1. A detailed description of the rearing systems and field information can be found at García-Casco et al. (2013). The subcutaneous tissue sampling of slaughtered animals was performed following the established Official method (B.O.E., 2004), as well as the extraction and esterification of lipids.

\subsection{Gas Chromatography}

Gas Chromatography (GC-FID) was carried out following the Official method (B.O.E., 2004). We used two Perkin Elmer chromatographs with autosamplers and a fused silica capillary column (30 $\mathrm{m} \times 0.32 \mathrm{~mm}$ internal diameter and $0.25 \mu \mathrm{m}$ film thickness). The injector temperature was kept at
Table 1

Sample classification according to the four feeding categories established by Official Quality Standards (B.O.E., 2007a) derived from field information

\begin{tabular}{cccccc}
\hline Campaign & Total & Bellota & Recebo & Campo & Cebo \\
\hline 2009 & 200 & 69 & 67 & 33 & 31 \\
2010 & 200 & 52 & 50 & 74 & 24 \\
2011 & 334 & 135 & 72 & 47 & 80 \\
Total & $\mathbf{7 3 4}$ & $\mathbf{2 5 6}$ & $\mathbf{1 8 9}$ & $\mathbf{1 5 4}$ & $\mathbf{1 3 5}$ \\
\hline
\end{tabular}

$230{ }^{\circ} \mathrm{C}$ and the detector temperature was $250{ }^{\circ} \mathrm{C}$, with helium as the carrier gas. The \% of 12 fatty acids (C12:0, C14:0, C16:0, C16:1, C17:0, C17:1, C18:0, C18:1, C18:2, C18:3, C20:0 and C20:1) are yields in these conditions.

\subsection{Gas chromatography-Combustion-Isotope ratio mass spectrometry}

The determination of the ${ }^{13} \mathrm{C} /{ }^{12} \mathrm{C}$ isotope ratio $\left(\delta{ }^{13} \mathrm{C}\right)$ of the fatty acids palmitic, stearic, oleic and linoleic using the technique GC-C-IRMS was made following the procedure described by Recio et al. (2010). We used an isotope ratio mass spectrometer with a continuous flow gas source, Hydra 20-20® model of SERCON Ltd, equipped with an electromagnet, a combustion interface and a Nafion membrane to retain water from the combustion product. To separate and transfer FAMEs to the spectrometer, a gas chromatograph Agilent 7890A GC System was used, with a capillary column, $30 \mathrm{~m} \times 0.25 \mathrm{~mm} \mathrm{ID}$ and 0.25 $\mu \mathrm{m}$ thickness, using $\mathrm{He}$ as the carrier gas. The injector temperature was $280^{\circ} \mathrm{C}$ and the detector was $300^{\circ} \mathrm{C}$. A combustion tube, comprised of a ceramic furnace with a copper oxide and platinum catalyst maintained at $860^{\circ} \mathrm{C}$, is used to obtain $\mathrm{CO}_{2}$ products from the separated FAMEs. Water is removed from the combustion gases by passing them through a Nafion membrane and then $\mathrm{CO}_{2}$ products are directed to the mass spectrometer.

Analyses were carried out in sets of 10 unknown samples, with standard samples at the beginning, middle and end of each series. As standards, three commercial FAMEs (Methyl-hexadecanoate, Methyl-heptadecanoate and Methyl-heneicosanoate from Sigma-Aldrich) were used, which were characterized by elemental analyzers of different national research centers coordinated by the stable isotope laboratory of the University of Salamanca. Additionally, a reference material of Iberian pig subcutaneous fat characterized (known values of isotopic ratios) by the stable isotope laboratory of the University of Salamanca and our own laboratory was used as a control.

The isotopic value obtained is expressed in terms of " $\delta$ " which represents the excess, typically heavy isotope, in a sample relative to a gas reference, \% o units, referred to PDB (Pee Dee Belemnite; 
international reference data $\delta{ }^{13} \mathrm{C}$ ). A regression line of the three internal standards analyzed along with the unknown samples was used to normalize the measured values. The following Goodman and Brenna formula (1992) was applied to obtain the FAMEs isotopic value discounting the contribution of the methylating agent: $\delta_{\mathrm{R}}=\left(\left(\mathrm{M}_{\mathrm{m}} \times \delta_{\mathrm{m}}\right)-\left(\mathrm{M}_{\mathrm{met}} \mathrm{x}\right.\right.$ $\left.\left.\delta_{\text {met }}\right)\right) / M_{R}$, where $\delta_{R}$ is the FAME isotope actual value, $M_{m}$ the number of moles of the measured species, $\delta_{m}$ the isotopic value measured, $M_{\text {met }}$ the number of moles of $C$ in methanol (1), $\delta_{\text {met }}$ the isotopic value of the methanol used and $M_{R}$ the number of moles of $\mathrm{C}$ in the FAME.

\subsection{Statistical analysis and Models}

Statistical analysis of the data was carried out with Statgraphics Centurion XVI.I (2011) to calculate the mean values, standard deviations, ANOVA and Fisher's LSD multiple range tests with a confidence level of $95 \%$.

A linear discriminant analysis by Statgraphics Centurion XVI.I (2011) was applied for the prediction of the feeding of pigs where the same probability for all groups had been established. We studied a total of five different models of discriminant analysis, based on the values used as the basis of the model:

1-FA4: percentage of the four major fatty acids obtained by GC-FID

2-FA12: percentage of the twelve fatty acids obtained by GC-FID.

$3-14:{ }^{13} \mathrm{C} /{ }^{12} \mathrm{C}$ isotope ratios of the four major fatty acids.
4-FA12-14: percentage of the twelve fatty acids and isotopic ratios of the four major fatty acids.

5-FA12-I4-C: percentage of twelve fatty acids and four major fatty isotopic ratios, differentiating the campaign in the classification criteria.

The results were also compared with the classification of the samples based on the criteria established in the Official Method (B.O.E., 2007b), based on the values of the four major fatty acids (results coded as 0-FA-QS).

\section{RESULTS AND DISCUSSION}

Table 2 shows the mean values and standard deviations obtained from the percentage of the major fatty acids (GC-FID) and its $\delta{ }^{13} \mathrm{C}$ isotopic values obtained by GC-C-IRMS. As shown, the percentage of $\mathrm{C} 16: 0$ and $\mathrm{C} 18: 0$ is very similar in all lots of Bellota with no significant differences among the three lots after an ANOVA analysis and, therefore, no significance in the multiple range test (Table 3). There were significant differences among campaigns for the percentages of $\mathrm{C} 18: 1$ and $\mathrm{C} 18: 2$ in the ANOVA analysis, with the 2010 campaign mean (dry and scarce acorns) being lower when compared to the other two campaigns (Table 3 ). However, the values of C18:2 follow the opposite trend, with higher in low-income campaigns as the 2010 and lower in 2011, which was a rainy year (Narváez-Rivas et al., 2009), with significant differences between them. The percentages of C16:0 and C18:0 increase progressively in batches of Recebo, Campo and Cebo, while the C18:1 decreases in the same direction. The exception is

Table 2

Mean values of \% fatty acids and isotopic ratio by CG y GC-C-IRMS

\begin{tabular}{|c|c|c|c|c|c|c|c|c|c|}
\hline & \multirow{2}{*}{ Campaign } & \multicolumn{4}{|c|}{$\%$ by CG-FID } & \multicolumn{4}{|c|}{$\delta^{13} \mathrm{C}$ by GC-C-IRMS ${ }^{b}$} \\
\hline & & C16:0 & C18:0 & C18:1 & C18:2 & $\mathrm{C} 16: 0$ & C18:0 & C18:1 & C18:2 \\
\hline \multirow[t]{3}{*}{ Bellota } & 2009 & $20,03 \pm 0,96$ & $9,16 \pm 1,02$ & $55,41 \pm 2,19$ & $9,39 \pm 0,66$ & $-25,5 \pm 1,6$ & $-22,9 \pm 1,9$ & $-27,1 \pm 1,5$ & $-32,3 \pm 1,3$ \\
\hline & 2010 & $20,06 \pm 0,86$ & $9,22 \pm 0,92$ & $54,56 \pm 1,90$ & $9,69 \pm 0,50$ & $-24,5 \pm 0,9$ & $-22,1 \pm 0,9$ & $-25,8 \pm 0,8$ & $-31,7 \pm 0,6$ \\
\hline & 2011 & $20,09 \pm 0,81$ & $9,15 \pm 0,99$ & $55,76 \pm 1,60$ & $8,77 \pm 0,98$ & $-27,3 \pm 0,7$ & $-24,6 \pm 0,8$ & $-28,1 \pm 0,7$ & $-33,8 \pm 0,6$ \\
\hline \multirow[t]{3}{*}{ Recebo } & 2009 & $20,89 \pm 1,49$ & $10,04 \pm 1,52$ & $52,16 \pm 2,51$ & $10,27 \pm 0,87$ & $-23,6 \pm 1,5$ & $-20,7 \pm 1,6$ & $-24,6 \pm 1,6$ & $-30,3 \pm 0,7$ \\
\hline & 2010 & $20,92 \pm 0,62$ & $9,95 \pm 0,91$ & $52,56 \pm 1,12$ & $9,9 \pm 0,52$ & $-24,5 \pm 0,9$ & $-22,4 \pm 1,1$ & $-25,8 \pm 0,8$ & $-31,2 \pm 0,8$ \\
\hline & 2011 & $20,40 \pm 1,05$ & $9,74 \pm 1,25$ & $54,77 \pm 1,94$ & $8,81 \pm 1,49$ & $-25,9 \pm 2,0$ & $-23,1 \pm 2,0$ & $-26,5 \pm 1,7$ & $-32,6 \pm 1,9$ \\
\hline \multirow[t]{3}{*}{ Campo } & 2009 & $21,59 \pm 1,51$ & $11,20 \pm 1,29$ & $51,10 \pm 4,17$ & $9,42 \pm 1,51$ & $-23,2 \pm 1,6$ & $-20,2 \pm 1,5$ & $-23,9 \pm 1,8$ & $-29,8 \pm 1,1$ \\
\hline & 2010 & $21,63 \pm 0,61$ & $10,61 \pm 1,15$ & $52,25 \pm 2,47$ & $8,65 \pm 1,10$ & $-24,6 \pm 1,6$ & $-22,6 \pm 1,6$ & $-25,1 \pm 1,4$ & $-30,8 \pm 1,4$ \\
\hline & 2011 & $21,29 \pm 0,68$ & $12,38 \pm 1,28$ & $52,09 \pm 1,15$ & $8,47 \pm 0,53$ & $-26,4 \pm 0,3$ & $-23,9 \pm 0,3$ & $-26,5 \pm 0,3$ & $-32,9 \pm 0,4$ \\
\hline \multirow[t]{3}{*}{ Cebo } & 2009 & $23,02 \pm 0,79$ & $13,00 \pm 1,02$ & $49,82 \pm 1,04$ & $7,64 \pm 0,65$ & $-24,5 \pm 0,3$ & $-21,9 \pm 0,5$ & $-24,1 \pm 0,6$ & $-31,9 \pm 0,5$ \\
\hline & 2010 & $22,99 \pm 0,74$ & $11,26 \pm 1,00$ & $48,50 \pm 1,32$ & $10,39 \pm 0,82$ & $-26,4 \pm 0,3$ & $-24,2 \pm 0,6$ & $-26,5 \pm 0,5$ & $-33,3 \pm 0,6$ \\
\hline & 2011 & $22,58 \pm 1,34$ & $11,93 \pm 1,56$ & $51,61 \pm 1,89$ & $7,18 \pm 1,07$ & $-24,4 \pm 1,8$ & $-21,8 \pm 1,9$ & $-25,2 \pm 1,2$ & $-32,2 \pm 0,9$ \\
\hline
\end{tabular}

Values of the four major fatty acids as \% of total fatty acids analyzed by GC-FID (a) and $\delta^{13} \mathrm{C} \%$ by GC-C-IRMS (b). Data are means \pm standard deviation. 
Table 3

Significant differences among campaigns in the same fatty acid and analytical technique

\begin{tabular}{|c|c|c|c|c|c|c|c|c|c|}
\hline \multirow{2}{*}{ Category } & \multirow{2}{*}{ Campaigns } & \multicolumn{4}{|c|}{$\%$ by CG-FID ${ }^{a}$} & \multicolumn{4}{|c|}{$\delta^{13} \mathrm{C}$ by GC-C-IRMS ${ }^{b}$} \\
\hline & & C16:0 & C18:0 & C18:1 & C18:2 & C16:0 & C18:0 & C18:1 & C18:2 \\
\hline \multirow[t]{3}{*}{ Bellota } & $2009-2010$ & & & * & & * & * & * & * \\
\hline & 2009-2011 & & & & * & * & * & * & * \\
\hline & $2010-2011$ & & & * & * & * & * & * & * \\
\hline \multirow[t]{3}{*}{ Recebo } & $2009-2010$ & & & & & * & * & * & * \\
\hline & $2009-2011$ & * & & * & * & * & * & * & * \\
\hline & $2010-2011$ & * & & * & * & * & * & * & * \\
\hline \multirow[t]{3}{*}{ Campo } & $2009-2010$ & & * & * & * & * & * & * & * \\
\hline & 2009-2011 & & * & & * & * & * & * & * \\
\hline & $2010-2011$ & * & * & & & * & * & * & * \\
\hline \multirow[t]{3}{*}{ Cebo } & 2009-2010 & & * & * & * & * & * & * & * \\
\hline & 2009-2011 & & * & * & * & & & * & \\
\hline & $2010-2011$ & & * & * & * & * & * & * & * \\
\hline
\end{tabular}

* Significant differences for $p<0.05$ with the Fisher's LSD multiple range Test.

in the batch Recebo 2011, where the average value is higher in oleic acid (54.77\%), close to the values obtained in the category of Bellota. The C18:2 shows great variability among campaigns and categories as it depends on the type of formulated feed used in the previous fattening stages.

For isotopic ratios there are no clear trends regarding the feeding categories since there are significant variations depending on the campaign (Table 3). So the ${ }^{13} \mathrm{C} /{ }^{12} \mathrm{C}$ mean isotope ratio obtained from the FAME of oleic acid, of the Bellota category in the campaigns of 2009 and 2011 are of greater magnitude $(-27.1$ and -28.1 , respectively) while in the 2010 campaign the mean isotope ratio is $-25.8 \%$, similar to that obtained in other categories in different campaigns (eg Recebo and Campo in 2011, Cebo and Recebo in 2010). These values indicate the difficulty of establishing a $\delta^{13} \mathrm{C}$ value that allows for classification based on the feeding system, because Bellota values of a dry campaign like 2010 are of the same order as those of Campo and Recebo of a rainy campaign like 2011 and even that of animals fed exclusively with formulated feed.

It is important to mention the high standard deviation within the same analytical value, feeding system and campaign of the great variety of samples that exist in the study.

\subsection{Models of discriminant analysis}

The prediction of the classification of samples based on the type of feed was carried out by a discriminant analysis with the five models previously described, which are differentiated by the values included in the analysis. The results were compared with the Official Method based on the percentage of the four major fatty acids. Tables 4, 5 and 6 show the prediction made and the percentage of success in each campaign and feeding type. Table 7 contains a summary of the overall rate of success of each model when considering four, three or two categories.

When applied according to the Official classification values (B.O.E., 2007b) for each category, the overall accuracy of the results is $66 \%$, $44 \%$ and $76 \%$ in the three categories considered (Cebo, Recebo and Bellota, Table 4), although not distinguishable between Cebo and Campo. The number of false positives in the Bellota category (misclassification of a lower category in this one) is very high: 63 Recebo animals (33\%) and 46 of Cebo/Campo (16\%).

Statistical models show that the success rate increases as the number of variables included in the discriminant analysis increases, and dramatically reduces false positives in the category of Bellota. Comparing the results by considering only three categories (Bellota, Recebo and Cebo), increasing from 4 to 12 fatty acids (1-FA4 models of Table 4 and 2-FA12 in Table 5) is an improvement in the prediction, especially in the category of Recebo (from $34 \%$ to $53 \%$ ), with an overall increase in the correct percentage of $8 \%$ (from $65 \%$ to $73 \%$, Table $7)$. The results are not very different between the 2-FA12 and 3-14 models (discriminant analysis with four isotopic ratios) of Table 5. However, by combining both techniques in the analysis (4-FA12-14, Table 6) the correct percentage increases 10 points, reaching $82 \%$, with results in each category of $91 \%$ in Cebo/Campo (formulated feed), $66 \%$ in Recebo and $83 \%$ in Bellota. If environmental factors, such as campaigns, are 
Table 4

Prediction of the sample classification according to the feeding category as Official Quality Standard (0-FA-QS) and the discriminant model 1-FA4

\begin{tabular}{|c|c|c|c|c|c|c|c|c|}
\hline \multicolumn{9}{|c|}{ 0-FA-QS Prediction } \\
\hline Category & Campaign & Cebo & Campo & Cebo/Campo & Recebo & Bellota & Total & Success \\
\hline \multirow[t]{3}{*}{ CEBO } & 2009 & & & 30 & 1 & & 31 & $97 \%$ \\
\hline & 2010 & & & 23 & 1 & & 24 & $96 \%$ \\
\hline & 2011 & & & 51 & 16 & 13 & 80 & $64 \%$ \\
\hline \multirow[t]{3}{*}{ CAMPO } & 2009 & & & 22 & 5 & 6 & 33 & $67 \%$ \\
\hline & 2010 & & & 29 & 22 & 23 & 74 & $39 \%$ \\
\hline & 2011 & & & 36 & 7 & 4 & 47 & $77 \%$ \\
\hline \multicolumn{2}{|c|}{ Total Cebo/Campo } & & & 191 & 52 & 46 & 289 & $66 \%$ \\
\hline \multirow[t]{3}{*}{ RECEBO } & 2009 & & & 30 & 32 & 5 & 67 & $48 \%$ \\
\hline & 2010 & & & 5 & 30 & 15 & 50 & $60 \%$ \\
\hline & 2011 & & & 7 & 22 & 43 & 72 & $31 \%$ \\
\hline \multicolumn{2}{|c|}{ Total Recebo } & & & 42 & 84 & 63 & 189 & $44 \%$ \\
\hline \multirow[t]{3}{*}{ BELLOTA } & 2009 & & & 6 & 11 & 52 & 69 & $75 \%$ \\
\hline & 2010 & & & & 18 & 34 & 52 & $65 \%$ \\
\hline & 2011 & & & & 27 & 108 & 135 & $80 \%$ \\
\hline \multicolumn{3}{|c|}{ Total Bellota } & & 6 & 56 & 194 & 256 & $76 \%$ \\
\hline \multicolumn{9}{|c|}{ 1-FA4 Prediction } \\
\hline Category & Campaign & Cebo & Campo & Cebo/Campo & Recebo & Bellota & Total & Success \\
\hline \multirow[t]{3}{*}{ CEBO } & 2009 & 27 & 4 & 31 & & & 31 & $87 \%$ \\
\hline & 2010 & 10 & 5 & 15 & 9 & & 24 & $42 \%$ \\
\hline & 2011 & 59 & 11 & 70 & 6 & 4 & 80 & $74 \%$ \\
\hline \multicolumn{2}{|l|}{ Total Cebo } & 96 & 20 & 116 & 15 & 4 & 135 & $71 \%$ \\
\hline \multirow[t]{3}{*}{ CAMPO } & 2009 & 7 & 13 & 20 & 4 & 9 & 33 & $39 \%$ \\
\hline & 2010 & 12 & 37 & 49 & 12 & 13 & 74 & $50 \%$ \\
\hline & 2011 & 5 & 36 & 41 & 4 & 12 & 47 & $77 \%$ \\
\hline \multicolumn{2}{|c|}{ Total Campo } & 24 & 86 & 110 & 20 & 34 & 154 & $56 \%$ \\
\hline \multicolumn{2}{|c|}{ Total Cebo/Campo } & 120 & 106 & 226 & 35 & 38 & 289 & $78 \%$ \\
\hline \multirow[t]{3}{*}{ RECEBO } & 2009 & 9 & 20 & 29 & 16 & 22 & 67 & $24 \%$ \\
\hline & 2010 & & 9 & 9 & 39 & 2 & 50 & $78 \%$ \\
\hline & 2011 & 2 & 17 & 19 & 10 & 43 & 72 & $14 \%$ \\
\hline \multicolumn{2}{|c|}{ Total Recebo } & 11 & 46 & 57 & 65 & 67 & 189 & $34 \%$ \\
\hline \multirow[t]{3}{*}{ BELLOTA } & 2009 & & 7 & 7 & 7 & 55 & 69 & $80 \%$ \\
\hline & 2010 & & 2 & 2 & 24 & 26 & 52 & $50 \%$ \\
\hline & 2011 & & 9 & 9 & 22 & 104 & 135 & $77 \%$ \\
\hline \multicolumn{2}{|c|}{ Total Bellota } & 0 & 18 & 18 & 53 & 185 & 256 & $72 \%$ \\
\hline
\end{tabular}

taken into account in the analysis (5-FA12-14-C, Table 6), the overall percentage of correct samples increased to $85 \%(94 \%$ in Cebo/Campo, $71 \%$ in Recebo and $85 \%$ in Bellota). Figure 1 shows the discriminant function model 4-FA12-14, where it can be seen that there is a clear separation between groups of Bellota, Cebo and Campo, while the Recebo group is a mixture of Bellota and Campo, with a higher number of misclassifications in this category. The inclusion of the environmental factor of each campaign helps to increase the accuracy in the Recebo category. 
Table 5

Prediction of sample classification according to the feeding category as 2-FA12 and 3-14 discriminant models

\begin{tabular}{|c|c|c|c|c|c|c|c|c|}
\hline \multicolumn{9}{|c|}{ 2-FA12 Prediction } \\
\hline Category & Campaign & Cebo & Campo & Cebo/Campo & Recebo & Bellota & Total & Success \\
\hline \multirow[t]{3}{*}{ CEBO } & 2009 & 30 & 1 & 31 & & & 31 & $97 \%$ \\
\hline & 2010 & 24 & & 24 & & & 24 & $100 \%$ \\
\hline & 2011 & 67 & 4 & 71 & 8 & 1 & 80 & $84 \%$ \\
\hline \multicolumn{2}{|l|}{ Total Cebo } & 121 & 5 & 126 & 8 & 1 & 135 & $90 \%$ \\
\hline \multirow[t]{3}{*}{ CAMPO } & 2009 & 4 & 15 & 19 & 6 & 8 & 33 & $45 \%$ \\
\hline & 2010 & & 52 & 52 & 18 & 4 & 74 & $70 \%$ \\
\hline & 2011 & 4 & 40 & 44 & 2 & 1 & 47 & $85 \%$ \\
\hline \multicolumn{2}{|c|}{ Total Campo } & 8 & 107 & 115 & 26 & 13 & 154 & $69 \%$ \\
\hline \multicolumn{2}{|c|}{ Total Cebo/Campo } & 129 & 112 & 241 & 34 & 14 & 289 & $83 \%$ \\
\hline \multirow[t]{3}{*}{ RECEBO } & 2009 & & 12 & 12 & 30 & 25 & 67 & $45 \%$ \\
\hline & 2010 & & 13 & 13 & 34 & 3 & 50 & $68 \%$ \\
\hline & 2011 & 8 & 13 & 21 & 37 & 14 & 72 & $51 \%$ \\
\hline \multicolumn{2}{|c|}{ Total Recebo } & 8 & 38 & 46 & 101 & 42 & 189 & $53 \%$ \\
\hline \multirow[t]{3}{*}{ BELLOTA } & 2009 & & 3 & 3 & 11 & 55 & 69 & $80 \%$ \\
\hline & 2010 & & 4 & 4 & 17 & 31 & 52 & $60 \%$ \\
\hline & 2011 & & 7 & 7 & 20 & 108 & 135 & $80 \%$ \\
\hline \multicolumn{2}{|c|}{ Total Bellota } & 0 & 14 & 14 & 48 & 194 & 256 & $76 \%$ \\
\hline \multicolumn{9}{|c|}{ 3-14 Prediction } \\
\hline Category & Campaign & Cebo & Campo & Cebo/Campo & Recebo & Bellota & Total & Success \\
\hline \multirow[t]{3}{*}{ CEBO } & 2009 & 23 & 7 & 30 & & 1 & 31 & $74 \%$ \\
\hline & 2010 & 14 & 10 & 24 & & & 24 & $58 \%$ \\
\hline & 2011 & 56 & 6 & 62 & 2 & 16 & 80 & $70 \%$ \\
\hline \multicolumn{2}{|l|}{ Total Cebo } & 93 & 23 & 116 & 2 & 17 & 135 & $69 \%$ \\
\hline \multirow[t]{3}{*}{ CAMPO } & 2009 & & 16 & 16 & 17 & & 33 & $48 \%$ \\
\hline & 2010 & 11 & 58 & 69 & 5 & & 74 & $78 \%$ \\
\hline & 2011 & 16 & 25 & 41 & 6 & & 47 & $53 \%$ \\
\hline \multicolumn{2}{|c|}{ Total Campo } & 27 & 99 & 126 & 28 & 0 & 154 & $64 \%$ \\
\hline \multicolumn{2}{|c|}{ Total Cebo/Campo } & 120 & 122 & 242 & 30 & 17 & 289 & $84 \%$ \\
\hline \multirow[t]{3}{*}{ RECEBO } & 2009 & 6 & 15 & 21 & 46 & & 67 & $69 \%$ \\
\hline & 2010 & 13 & 19 & 32 & 11 & 7 & 50 & $22 \%$ \\
\hline & 2011 & 18 & 5 & 23 & 24 & 25 & 72 & $33 \%$ \\
\hline \multicolumn{2}{|c|}{ Total Recebo } & 37 & 39 & 76 & 81 & 32 & 189 & $43 \%$ \\
\hline \multirow[t]{3}{*}{ BELLOTA } & 2009 & 4 & 1 & 5 & 10 & 54 & 69 & $78 \%$ \\
\hline & 2010 & 13 & 6 & 19 & 20 & 13 & 52 & $25 \%$ \\
\hline & 2011 & 8 & & 8 & 2 & 125 & 135 & $93 \%$ \\
\hline \multicolumn{2}{|c|}{ Total Bellota } & 25 & 7 & 32 & 32 & 192 & 256 & $75 \%$ \\
\hline
\end{tabular}

A detailed analysis of samples misclassified by the model 5 (FA12-I4-C) allows one to appreciate that from the 38 misclassified simples of Bellota, 23 present fatty acid percentages and isotopic ratios lower than usual in this category (specifically, 18 samples show \% oleic acid less than $53 \%, 2$ exhibit 
Table 6

Prediction of sample classification according to the feeding category as 4-FA12-I4 and 5 FA12-I4-C discriminant models

\begin{tabular}{|c|c|c|c|c|c|c|c|c|}
\hline \multicolumn{9}{|c|}{ 4-FA12-I4 Prediction } \\
\hline Category & Campaign & Cebo & Campo & Cebo/Campo & Recebo & Bellota & Total & Success \\
\hline \multirow[t]{3}{*}{ CEBO } & 2009 & 30 & 1 & 31 & & & 31 & $97 \%$ \\
\hline & 2010 & 24 & & 24 & & & 24 & $100 \%$ \\
\hline & 2011 & 73 & 1 & 74 & 5 & 1 & 80 & $91 \%$ \\
\hline \multicolumn{2}{|l|}{ Total Cebo } & 127 & 2 & 129 & 5 & 1 & 135 & $94 \%$ \\
\hline \multirow[t]{3}{*}{ CAMPO } & 2009 & & 23 & 23 & 10 & & 33 & $70 \%$ \\
\hline & 2010 & 1 & 64 & 65 & 9 & & 74 & $86 \%$ \\
\hline & 2011 & 4 & 43 & 47 & & & 47 & $91 \%$ \\
\hline \multicolumn{2}{|c|}{ Total Campo } & 5 & 130 & 135 & 19 & 0 & 154 & $84 \%$ \\
\hline \multicolumn{2}{|c|}{ Total Cebo/Campo } & 132 & 132 & 264 & 24 & 1 & 289 & $91 \%$ \\
\hline \multirow[t]{3}{*}{ RECEBO } & 2009 & & 9 & 9 & 55 & 3 & 67 & $82 \%$ \\
\hline & 2010 & & 9 & 9 & 30 & 11 & 50 & $60 \%$ \\
\hline & 2011 & 9 & 7 & 16 & 40 & 16 & 72 & $56 \%$ \\
\hline \multicolumn{2}{|c|}{ Total Recebo } & 9 & 25 & 34 & 125 & 30 & 189 & $66 \%$ \\
\hline \multirow[t]{3}{*}{ BELLOTA } & 2009 & & & 0 & 12 & 57 & 69 & $83 \%$ \\
\hline & 2010 & & 2 & 2 & 21 & 29 & 52 & $56 \%$ \\
\hline & 2011 & 1 & 1 & 2 & 7 & 126 & 135 & $93 \%$ \\
\hline \multicolumn{2}{|c|}{ Total Bellota } & 1 & 3 & 4 & 40 & 212 & 256 & $83 \%$ \\
\hline \multicolumn{9}{|c|}{ 5-FA12-I4-C Prediction } \\
\hline Category & Campaign & Cebo & Campo & Cebo/Campo & Recebo & Bellota & Total & Success \\
\hline \multirow[t]{3}{*}{ CEBO } & 2009 & 31 & & 31 & & & 31 & $100 \%$ \\
\hline & 2010 & 24 & & 24 & & & 24 & $100 \%$ \\
\hline & 2011 & 72 & 2 & 74 & 2 & 4 & 80 & $90 \%$ \\
\hline \multicolumn{2}{|l|}{ Total Cebo } & 127 & 2 & 129 & 2 & 4 & 135 & $94 \%$ \\
\hline \multirow[t]{3}{*}{ CAMPO } & 2009 & 4 & 29 & 33 & & & 33 & $88 \%$ \\
\hline & 2010 & & 64 & 64 & 8 & 2 & 74 & $86 \%$ \\
\hline & 2011 & 2 & 44 & 46 & 1 & & 47 & $94 \%$ \\
\hline \multicolumn{2}{|c|}{ Total Campo } & 6 & 137 & 143 & 9 & 2 & 154 & $89 \%$ \\
\hline \multicolumn{2}{|c|}{ Total Cebo/Campo } & 133 & 139 & 272 & 11 & 6 & 289 & $94 \%$ \\
\hline \multirow[t]{3}{*}{ RECEBO } & 2009 & & 14 & 14 & 48 & 5 & 67 & $72 \%$ \\
\hline & 2010 & & 3 & 3 & 40 & 7 & 50 & $80 \%$ \\
\hline & 2011 & 3 & 10 & 13 & 46 & 13 & 72 & $64 \%$ \\
\hline \multicolumn{2}{|c|}{ Total Recebo } & 3 & 27 & 30 & 134 & 25 & 189 & $71 \%$ \\
\hline \multirow[t]{3}{*}{ BELLOTA } & 2009 & & & 0 & 6 & 63 & 69 & $91 \%$ \\
\hline & 2010 & & 2 & 2 & 16 & 34 & 52 & $65 \%$ \\
\hline & 2011 & & & 0 & 14 & 121 & 135 & $90 \%$ \\
\hline \multicolumn{2}{|c|}{ Total Bellota } & 0 & 2 & 2 & 36 & 218 & 256 & $85 \%$ \\
\hline
\end{tabular}

$\%$ linolenic acid over $11 \%$ and 19 show $\delta{ }^{13} \mathrm{C}$ of oleic acid over $-26 \%$ o), so they should be reclassified to the category of Recebo. The final number of Bellota samples misclassified are reduced to 15 , ie, only $6 \%$ of all samples in this category. Furthermore, in the category of Cebo/Campo only 17 samples 
Table 7

Correct percentage for all models according to the number of categories considered

\begin{tabular}{lcccccc}
\hline \multicolumn{7}{c}{ Correct percentage } \\
\hline \multicolumn{1}{c}{ Category number } & 0-FA-QS & 1-FA4 & 2-FA12 & 3-14 & 4-FA12-I4 & 5-FA12-I4-C \\
\hline 4 (B/R/CA/CE) & & $59 \%$ & $71 \%$ & $63 \%$ & $81 \%$ & $84 \%$ \\
$3(\mathrm{~B} / \mathrm{R} / \mathrm{CE})$ & $64 \%$ & $65 \%$ & $73 \%$ & $70 \%$ & $82 \%$ & $85 \%$ \\
2 (B/CE) & $77 \%$ & $77 \%$ & $84 \%$ & $85 \%$ & $90 \%$ & $91 \%$ \\
\hline
\end{tabular}

B: Bellota, R: Recebo, CA: Campo and CE: Cebo

$(6 \%)$ are erroneously classified, with a drastic reduction in false positives to 6 samples $(2 \%)$ in Bellota. In the case of animals from the Recebo category which presents increased difficulty of prediction, 55 animals were incorrectly classified (29\%). In 18 samples out of 30 framed in the Cebo/ Campo category the oleic acid percentage was less than $51 \%$ and/or the isotopic ratio of oleic acid was higher than $-23 \%$, ie below the normal rate category, which should be reclassified as Cebo/Campo despite qualifying it as Recebo. The false positives of 25 samples classified as Bellota $(13 \%)$ belong to batches in which the weight gain obtained by pigs during the consumption of acorns and grass was very high, close to that required for the category of Bellota.

\section{CONCLUSIONS}

The discriminant analysis using the values of 12 fatty acids obtained by Gas Chromatography and four isotope ratios by CG-C-IRMS, as well as the inclusion of the environmental factor of each campaign, provide a necessary basis for a correct classification of subcutaneous adipose tissue samples of Iberian pigs according to the type of feed received during fattening.

This paper shows that combining both instrumental methods, GC-FID and GC-C-
IRMS, predictions are improved when we aim to classify large numbers of samples from different geographical areas, in campaigns with different acorn production and quality in the case of animals of Recebo and Bellota, and pigs fattened with different types of formulated feed for Cebo and Campo.

The Recebo category shows a wide range of variability, hence the difficulty for a correct prediction. Depending on the quantity and the quality of the acorns and the harvest, which is different among geographical zones, some animals are classified as Recebo or as Cebo/Campo, depending on the above factors.

The consideration of only two categories significantly increases the level of accuracy in the prediction model 5-FA12-I4-C.

The use of this model complemented with actual field data, would classify pigs according to current regulations and would provide essential information for the correct labelling of products, with the consequent benefits for the consumer.

\section{ACKNOWLEDGEMENTS}

Samples that have made this work possible come from an RTA08-26 INIA funded project and CC08-31 from the Ministerio de Agricultura, Alimentación y Medio Ambiente (Spain). The

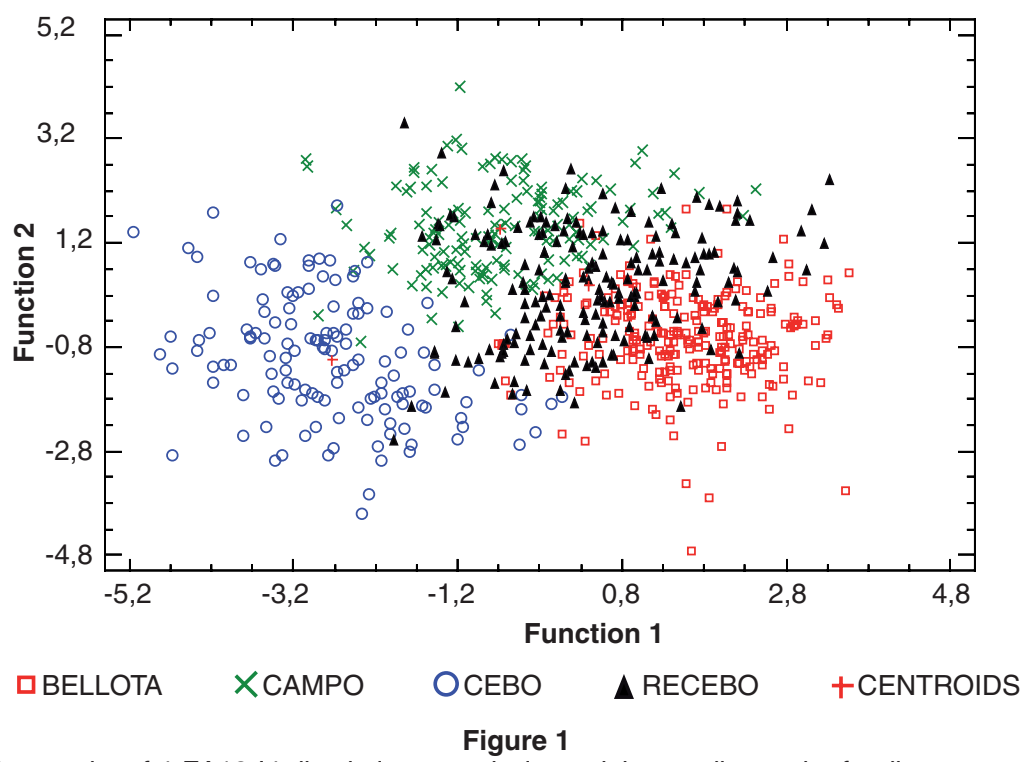

Scatterplot of 4-FA12-I4 discriminant analysis model according to the feeding category 
analytical determinations were performed in the laboratory of the interprofessional $\mathrm{ASICl}$ supported by Quality standard extension studies (B.O.E., 2010). The authors thank Dr. Clemente Recio Hernández for his assistance with the implementation of the technical CG-C-IRMS.

\section{REFERENCES}

Boletín Oficial del Estado (B.O.E.) 2004. ORDEN PRE/3844/2004, de 18 de noviembre, por la que se establecen los métodos oficiales de toma de muestras en canales de cerdos ibéricos y el método de análisis para la determinación de la composición de ácidos grasos de los lípidos totales del tejido adiposo subcutáneo de cerdos ibéricos. 3877038779. Madrid, Spain.

Boletín Oficial del Estado (B.O.E.) 2007a. REAL DECRETO 1469/2007, de 2 de noviembre, por el que se aprueba la norma de calidad para la carne, el jamón, la paleta y la caña de lomo ibéricos. 4508745104. Madrid, Spain.

Boletín Oficial del Estado (B.O.E.) 2007b. ORDEN APA/3653/2007, de 13 de diciembre, por la que se publican los valores de ácidos grasos aplicables a las designaciones de alimentación «Bellota» y «Recebo», para la campaña 2007-2008. 51655. Madrid, Spain.

Boletín Oficial del Estado (B.O.E.) 2010. Orden ARM/2139/2010, de 16 de julio, por la que se extiende el Acuerdo de la Asociación Interprofesional del Cerdo Ibérico, al conjunto del sector, y se fija la aportación económica obligatoria, para realizar actividades de promoción de los productos del cerdo ibérico, mejorar la información y conocimiento sobre las producciones y los mercados, y realizar programas de investigación, desarrollo, innovación tecnológica y estudios, para las campañas 20102011, 2011-2012 y 2012-2013.68100-68102. Madrid, Spain.

Cava R, Andrés A. 2001. La obtención de material prima de una adecuada aptitud tecnológica. Características de la grasa determinantes de la calidad del jamón: influencia de los factores genéticos y ambientales, en Ventanas J (Ed). Tecnología del Jamón Ibérico. Ed. Mundi-Prensa, Madrid, Spain, 99-129.

De Niro MJ , Epstein S. 1978. Influence of diet on the distribution of carbon isotope ratios in animals. Geochim. Cosmochim. Acta 42, 495-506.

García-Casco JM, Muñoz M, González E. 2013. Predictive ability of the feeding system by means of several analytical methods in iberian pig. Grasas Aceites 64, 191-200.

García-Olmo J, Garrido-Varo A, De Pedro E. 2009. Classification of real farm conditions Iberian pigs according to the feeding regime with multivariate models developed by using fatty acids composition or NIR spectral data. Grasas Aceites 60, 233-237.

Gilles E. 2009. Dry cured ham quality as related to lipid quality of raw material and lipid changes during processing: a review. Grasas Aceites 60, 297-307.
Goodman KJ, Brenna JT. 1992. High sensitivity tracer detection using high-precision gas chromatographycombustion isotope ratio mass spectrometry and highly enriched [U-13C] precursors. Anal. Chem. 64, 1088-1095.

González Martín I, González Pérez C, Hernández Méndez J, Recio Hernández C, Sabio Rey E. 1998. Método para la caracterización y diferenciación del cerdo ibérico en función de la dieta. ES 2100130 B1.

González-Martín I, González-Pérez C, HernándezMéndez J, Marqués-Macias E, Sanz-Poveda F. 1999. Use of isotope analysis to characterize meat from iberian Breed Swine. Meat Sci. 52, 437-441.

González-Martín I, González-Pérez C, HernándezMéndez J, Sánchez-González C. 2001. Differentiation of dietary regimen of iberian swine by means of isotopic analysis of carbon and sulpur in hepatic tissue. Meat Sci. 58, 25-30.

Kelly SD, Parker I, Sharman M, Dennis MJ. 1997. Assessing the authenticity of single seed vegetable oils using fatty acid stable carbon isotope ratios $\left({ }^{13} \mathrm{C} /{ }^{12} \mathrm{C}\right)$. Food Chem. 59, 181-186.

Kelly SD, Rhodes C. 2002. Emerging Techniques in Vegetable Oil Analysis Using Stable Isotope Ratio Mass Spectrometry Grasas Aceites 53, 34-44.

Melgar J, Cid C, Astiasarán I, Bello J. 1991. Influencia de la alimentación del cerdo ibérico en las características de los compuestos relacionados con la grasa del jamón curado. Grasas Aceites. 42, 51-55.

Narváez-Rivas M, León-Camacho M, Vicario IM. 2009. Fatty acid and triacylglycerol composition of the subcutaneous fat from iberian pigs fattened on the traditional fee: "Montanera". Effect of anatomical location and length of feeding. Grasas Aceites 60, 238-247.

Recio Hernández C. 2010. Método de identificación de productos alimenticios. ES2 $326249 \mathrm{~B} 1$.

REGLAMENTO (CEE) No 2676/90 DE LA COMISIÓN de 17 de septiembre de 1990 por el que se determinan los métodos de análisis comunitarios aplicables en el sector del vino.

Ruiz J, Pretón MJ. 2001. Métodos para la clasificación de la materia prima, en Ventanas J (Ed). Tecnología del Jamón Ibérico. Ed. Mundi-Prensa, Madrid, Spain, 130-160.

Ruiz J, Ventanas J, Cava R, Andrés Al, García C. 2000. Texture and appearance of dry cured ham as affected by fat content and fatty acid composition. Food Research Int. 33, 91-95.

Spangenberg J E, Macko SA, Hunziker J. 1998. Characterization of olive oil by carbon isotope analysis of individual fatty acids: Implications for authentication. J. Agric. Food Chem. 46, 4179-4184.

Statgraphics Centurion XVI. 16.1.15 version. StatPoint Technologies, Inc. 1982-2011.

Ventanas J, Andrés AI, Cava R, Tejeda JF, y Ruiz J. 1999. Composición y características de la grasa en el cerdo Ibérico e influencia sobre la calidad del jamón. Cárnica 2000 Marzo, 55-59

Ventanas S, Estévez M, Tejeda JF, Ruiz J. 2006. Protein and lipid oxidation in dry cured loin as affected by crossbreeding and diet. Meat Sci. 72, 647-655. 